\title{
Communication and Change
}


THE EAST-WEST CENTER, established in Hawaii by the United States Congress in 1960, is a national educational institution with multinational programs. Its purpose is to promote better relations and understanding among the nations and peoples of Asia, the Pacific area, and the United States through their cooperative participation in research, study, and training activities.

Fundamental to the achievement of the Center's purpose are the cooperative discovery and application of knowledge and the interchange of knowledge, information, ideas, and beliefs in an intercultural atmosphere of academic freedom. In Center programs, theory and practice are combined to help current and future leaders generate, test, and share knowledge about important world problems of mutual concern to people in both East and West.

Each year about 1,500 scholars, leaders, public officials, mid-level and upper-level managers, and graduate students come to the Center to work and study together in programs concerned with seeking alternative approaches and solutions to common problems. For each participant from the United States, two come from the Asian/Pacific area. An international, interdisciplinary professional staff provides the framework, content, and continuity for programs and for cooperative relationships with universities and other institutions in the Center's area of operations.

Center programs are conducted by the East-West Communication Institute, the East-West Culture Learning Institute, the East-West Food Institute, the East-West Population Institute, and the East-West Technology and Development Institute. Each year the Center also awards a limited number of "Open Grants" for graduate degree education and research by scholars and authorities in areas not encompassed by the problem-oriented institutes.

The East-West Center is governed by the autonomous board of a public, nonprofit educational corporation - the Center for Cultural and Technical Interchange Between East and West, Inc.established by special act of the Hawaii State Legislature. The Board of Governors is composed of distinguished individuals from the United States and countries of Asia and the Pacific area. The United States Congress provides basic funding for Center programs and for a variety of scholarships, fellowships, internships, and other awards. Because of the cooperative nature of Center programs, financial support and cost-sharing arrangements also are provided by Asian and Pacific governments, regional agencies, private enterprise, and foundations.

The Center is located in Honolulu, Hawaii, on twenty-one acres of land adjacent to the University of Hawaii's Manoa campus. Through cooperative arrangements with the University of Hawaii, the Center has access to University degree programs, libraries, computer center, and the like.

East-West Center Books are published by The University Press of Hawaii to further the Center's aims and programs. 


\title{
Communication and Change \\ The Last Ten Years - and the Next
}

\author{
edited by \\ WILBUR SCHRAMM \\ DANIEL LERNER
}

AN EAST-WEST CENTER BOOK 五

Published for the East-West Center

by The University Press of Hawaii

Honolulu 
First edition 1976

Paperback 1978

Copyright (C) 1976 by The University Press of Hawaii

All rights reserved. No part of this work may be reproduced or transmitted in any form or by any means, electronic or mechanical, including photocopying and recording, or by any information storage or retrieval system, without permission in writing from the publisher.

Manufactured in the United States of America Composition by Asco Trade Typesetting Limited, Hong Kong Book design by Roger J. Eggers

Cover design by A.O.K. Hammond

\section{Library of Congress Cataloging in Publication Data}

Main entry under title:

Communication and change, the last ten years-and the next.

Papers presented at a conference held at the East-West Center, Honolulu, in Jan. 1975.

"An East-West Center book."

Bibliography: p.

Includes index.

1. Underdeveloped area-Communication. I. Schramm, Wilbur Lang, 1907-

P92.2.C6 301.14

II. Lerner, Daniel.

ISBN 0-8248-0446-5 